\title{
THE USE OF AN ARTIFICIAL NEURAL NETWORK TO PREDICT AUSTRALIA'S EXPORT AIR CARGO DEMAND
}

\author{
Glenn Baxter ${ }^{1,}$ Panarat Srisaeng ${ }^{2}$ \\ ${ }^{1,2}$ School of Tourism and Hospitality Management, Suan Dusit University, Huahin Campus, Huahin, \\ Prachaup Khiri Khan, Thailand
}

Received 20 October 2017; accepted 10 January 2018

\begin{abstract}
In this paper an Artificial Neural Network (ANN) is proposed for predicting Australia's annual export air cargo demand. The modelling in the study was based on annual data from 1993 to 2016. The ANN model was developed using the input parameters of world real merchandise exports, world population growth, world jet fuel prices, world air cargo yields (proxy for air cargo costs), outbound flights from Australia, and Australian/ United States dollar exchange rate and two dummy variables, which controlled for the strong cyclical fluctuations in air cargo demand which occurred in 2003 and 2015. The artificial neural network (ANN) used multi-layer perceptron (MLP) architecture that compromised a multi-layer feed-forward network and the sigmoid and linear functions were used as activation functions with the feed forward-back propagation algorithm. The ANN was applied during training, testing and validation and had 8 inputs, 1 neuron in the hidden layer and 1 neuron in the output layer. The data was randomly divided into three data sets; training, testing and model validation. The best-fit model was selected according to four goodness-of-fit measures: mean absolute error (MAE), mean square error (MSE), root mean square errors (RMSE), and mean absolute percentage errors (MAPE). The highest R-value obtained from the ANN model is 0.97844 . The results suggest that the ANN model is an efficient tool for predicting Australia's annual export air cargo demand.
\end{abstract}

Keywords: air cargo, artificial neural network, airlines, Australia, forecasting, Multi-Layer Perceptron.

\section{Introduction}

Because of Australia's relatively remote geographical location, the international air cargo mode plays a significant role in the country's international trade. Air and ocean transport are the only two modes available for any trade being shipped to or from Australia. In 1949-50 a very small volume and proportion of Australia's international trade were transported by air freight. In this early period, four aviation firms, British Commonwealth Airlines, Qantas Empire Airways Ltd, British Overseas Airways Corporation, and Tasman Empire Airways transported Australia's international air freight. The primary air cargo destinations were the South Pacific Islands, Hong Kong, London, Tokyo and Vancouver (Australian Bureau of Statistics, 2001). Since these humble beginnings, Australia's international air cargo mode has therefore become an integral part

\footnotetext{
${ }^{2}$ Corresponding author: panarat_sri@dusit.ac.th
} 
of Australia's economy. Timely and efficient air cargo services assist Australian firms to compete with rivals in export markets. The types of commodities exported from Australia by the air cargo mode are typically low bulk and high value, and/or time-sensitive (including perishable cargoes). Australia's export air cargo is principally carried in the lower deck belly holds of combination airlines passenger aircraft, with the balance carried by dedicated freight services (Productivity Commission, 1998). In 2016, sixty-one international scheduled airlines, including 5 dedicated all-cargo airlines, operated services to/from Australia (Bureau of Infrastructure, Transport and Regional Economics, 2017).

The long-term forecasting of air cargo demand is regarded as essential for government, airports and air freight operators for planning and investment decision making purposes (Hamal, 2011). Demand forecasting is also critical for analyzing existing cargo flight schedules and identifying air cargo-related firm's future facility requirements (Totamane et al., 2012). Despite the significance of the air freight mode to Australia's export trade, there has only been, to the best of the author's knowledge, one reported study that has modelled Australia's export air cargo demand. Hamal (2011) developed single equation models, which were specified in a double logarithmic linear functional form, to forecast Australia's import and export air cargo demand from 2009/2010 to $2029 / 2030$. The aim of this study is to develop and empirically test an artificial neural network (ANN) model for predicting Australia's export air cargo demand.

The remainder of the paper is organized as follows: Section 2 presents the ANN architecture, the study's data collection and variable selection, goodness-of-fit measures and the training and testing of the ANN. Section 3 summarises the empirical results. The study's conclusions and suggestions for future research are presented in Section 4.

\section{Artificial Neural Network Modelling}

\subsection{Artificial Neural Network Architecture}

The objective of an artificial neural network (ANN) is to make accurate predictions for the dependent variable (output cell) (Khan et al., 2015). ANNs capture the inherent information from a considered set of variables and learn from the existing data. This occurs even when noise is present (Garrido et al., 2014). Hence, no formulation or a priori model is required (Merkus and Meesters, 2013; Watts and Worner, 2008). An ANN can be trained to perform a particular function by adjusting the values of connections (weights) between the model's elements (Kunt et al., 2011). During the training process, the ANN can detect complex relationships between the input and output data and perform synthesis (Sineglazov et al., 2013). Once the ANN has been trained on the sample of the given dataset, it can make estimations through the detection of similar patterns in future data (BaFail, 2004).

ANNs can detect similarities in inputs, despite a particular input not being previously seen by the network. This property provides ANNs with excellent interpolation capabilities, especially when the input data may not be exact, that is, the data is noisy or not exact (Kashyap et al., 2017).

The most general form of an ANN used in forecasting is shown in the following equation: 


$$
\mathrm{Y}=\mathrm{F}[\mathrm{H} 1(\mathrm{x}), \mathrm{H} 2(\mathrm{x}) \ldots ., \mathrm{Hn}(\mathrm{x})]+\mathrm{u}
$$

Where, $\mathrm{Y}$ is a dependent variable, $\mathrm{X}$ is a set of explanatory variables, $\mathrm{F}$ and $\mathrm{H}$ 's are network functions, and $\mathrm{u}$ is a model error term (BaFail, 2004, p. 103).

The artificial neural network model is characterized by a network of three layers: input, output and hidden layers (Cocchi et al., 2017; Khan et al., 2015; Srisaeng et al., 2015). An ANN consists of a large number of simple processing elements called neurons. The neurons are organized into several layers and interconnected with each other through synaptic weights. Synaptic weights represent the intensity of the interaction between every pair of neurons, and the activation functions calculate the potential of every neuron (Dell'Olio et al., 2017; Garrido et al., 2014; Tiryaki and Aydın, 2014).

The most widely used type of ANN for prediction is the Multi-Layer Perceptron (MLP) model (Claveria and Torra, 2014; Garrido et al., 2014; Howard et al., 2012;
Nachev, 2008). The MLP is a supervised neural network based on the original simple perceptron model. Figure 1 presents the study's 3-layer back propagation network. The first layer is the input layer and corresponds to the problem input variables with one node for each input variable. The second layer is the hidden layer. This layer performs the operations that are designed to achieve the model's output (Tiryaki and Aydın, 2014). The hidden layer is also used to capture non-linear relationships among variables (Kar et al., 2015; Lahmiri and Gagnon, 2015). The third layer is the output layer. In the output layer each cell represents a dependent variable that the researchers are aiming to predict (Khan et al., 2015). The ANNs output layer provides the model's predicted values (Kar et al., 2015; Lahmiri and Gagnon, 2015). The number of neurons in the input layer is equal to the number of input variables or independent variables, and the number of output neurons is equal to the number of output variable(s) or dependent variable(s) (Srisaeng et al., 2015; Tiryaki and Aydın, 2014).

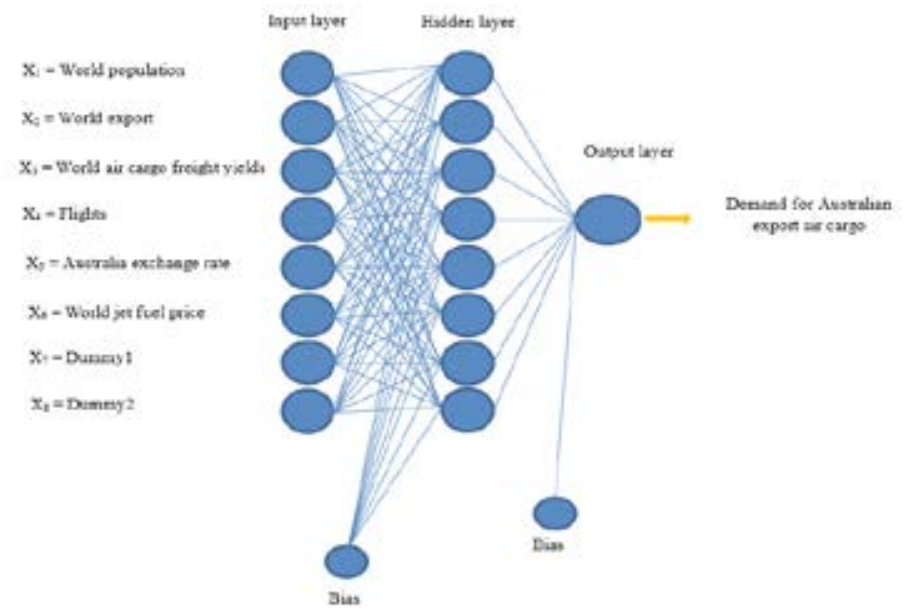

Fig. 1.

The Study's Artificial Neural Network Structure 
The general form of the MLP output can be expressed mathematically as per equation 2 .

$Y=g\left(\theta+\sum_{j=1}^{m} v_{j}+\left[\sum_{i=1}^{n} f\left(W_{i j} X_{i}+\beta_{j}\right)\right]\right)$

where, $Y$ is the prediction value of dependent variable; $X_{i}$ is the input value of $i$ th independent variable; $W_{i j}$ is the weight of connection between the $i$ th input neuron and $j$ th hidden neuron; $\beta_{j}$ is the bias value of the $j$ th hidden neuron; $v_{j}$ is the weight of connection between the $j$ th hidden neuron and output neuron; $\theta$ is the bias value of output neuron; $g($.$) and f($.$) are the$ activation functions of output and hidden neurons respectively (Tiryaki and Aydın, 2014).

\subsection{Variable Selection and Data Collection}

The factors that influence the demand for air cargo are complex in nature (Doganis, 2010). Prior to the data collection stage of the study an extensive literature review was undertaken to identify the various exogenous and endogenous factors that influence air cargo demand. Based on this analysis, six variables were considered as input variables in the ANN modelling (Table 1 ). These candidate variables were world merchandise trade (Cook and Billig, 2017; Kupfer et al., 2011), world air freight yields (a proxy for freight cost) (Boeing, 2016; International Civil Aviation Organization, 2001), world population growth (Airports Council International, 2004), world jet fuel prices (Boeing 2016, International Civil Aviation Organization, 2001), proliferation of points served (measured by outbound flights from Australia) (Boeing, 2016) and foreign exchange rates (measured by the Australia/United States foreign exchange rate) (Boeing, 2016; Hertwig and Rau,
2010). In addition, to the six input variables, three dummy variables were considered in the modelling to control for major factors that influenced the industry over the study period.

During 2003, both passenger and air cargo traffic recorded declines. Australia's export air cargo volumes in 2003 declined by 12.7 per cent. The factors that contributed to the downturn in passenger demand included the SARS crisis and the war in Iraq (Bureau of Transport and Regional Economics, 2004). Thus, the first dummy variable (DUMMY 1) accounted for the quite strong downturn in Australia's export air cargo demand in 2003. This dummy variable had a value of 1 in 2003 and 0 for all other years.

The second dummy variable (DUMMY 2) controlled for the influence of the Olympic Games held in Sydney in 2000. The Olympic Games ran for 17 days (the Opening Ceremony was held on 15 September 2000). The Paralympics were also staged in Sydney over a 12-day period shortly after the conclusion of the Olympic Games (Madden, 2002). During the Sydney Olympic Games, extra international services were operated to carry both passengers and air cargo for the Olympic Games. This dummy variable had a value of 1 in 2000 and 0 otherwise. During the ANN modelling process, this variable was found not to be significant and was therefore removed.

The types of products and commodities shipped by the air cargo mode have grown in recent times to include fashion items, perishable products, for example, fresh fruit and chilled meat, machinery, and electronics. This growth has been underpinned by shippers and manufacturers' adopting more and more just-in-time strategies as well as 
consumers increasingly desiring international products (Shields, 1998). Notwithstanding, these changing market dynamics have added to the volatility in air cargo demand. Fluctuations in demand of $+/-15$ to 20 per cent within one year are not uncommon. The major driver of these fluctuations in air cargo demand is the global economy, which is the primary driver of world trade, and hence, the demand for air cargo services (Hellermann, 2006). In 2015, Australia's export air cargo demand displayed such a trend, growing by 23.2 per cent (Bureau of Infrastructure, Transport and Regional Economics, 2016). Lefort (2016) noted that the strong expansion in Australian exports to Asia had resulted in strong demand for air cargo capacity, and, in some cases, demand exceeded the available air cargo capacity (Lefort, 2016). Thus, to control for this significant fluctuation in demand in 2015, a third dummy variable (DUMMY 3) was included in the modelling and had a value of 1 in 2015 and 0 for all other years.

The availability of a consistent data set allows the use of annual data for the period 1993 to 2016 . The variables included in the study and the data source are summarized in Table 1.

Table 1

Candidate Variables and Data Sources for Australia's Export Air Cargo Demand Model

\begin{tabular}{|l|l|l|}
\hline $\begin{array}{l}\text { Variable } \\
\text { Number }\end{array}$ & Variable Name & Data Source \\
\hline $\mathrm{X}_{1}$ & World population & International Monetary Fund \\
\hline $\mathrm{X}_{2}$ & World merchandise exports & World Trade Organization \\
\hline $\mathrm{X}_{3}$ & World air freight yield & Boeing Commercial Airplanes \\
\hline $\mathrm{X}_{4}$ & Outbound flights & Bureau of Infrastructure, Transport and Regional Economics \\
\hline $\mathrm{X}_{5}$ & AUD/USD exchange rate & Reserve Bank of Australia \\
\hline $\mathrm{X}_{6}$ & World jet fuel prices & International Energy Agency \\
\hline $\mathrm{Y}$ & Annual enplaned export air cargo tonnage & Bureau of Infrastructure, Transport and Regional Economics \\
\hline
\end{tabular}

To convert collected data from current prices to real or constant prices, consumer price index at 2011 constant prices was used (BaFail et al., 2000).

\subsection{Model Performance Goodness of Fit Measures}

To evaluate the performance of the study's ANN prediction model, the following error measures, were considered.

$$
M S E=\frac{1}{N} \sum_{i=1}^{N}\left(t_{i}-t d_{i}\right)^{2}
$$

$$
\begin{aligned}
& \text { RMSE }=\sqrt{\frac{1}{N} \sum_{i=1}^{N}\left(t_{i}-t d_{i}\right)^{2}} \\
& M A E=\frac{1}{N} \sum_{i=1}^{N}\left[\left|\frac{t_{i}-t d_{i}}{t_{i}}\right|\right] \\
& M A P E=\frac{1}{N}\left(\sum_{i=1}^{N}\left[\left|\frac{t_{i}-t d_{i}}{t_{i}}\right|\right]\right) \times 100
\end{aligned}
$$


Where $t_{i}$ is the measured values, $t_{i}$ is the predicted values, $\mathrm{N}$ is the total number of data, and $(\overline{\mathrm{td}})$ is the average of the predicted values (Tiryaki and Aydın, 2014, p. 104).

\subsection{Training and Testing the Artificial Neural Network}

For the ANN training process, the collected data was separated into three data sets: training, testing and validation. It is important to note that the validation data set is used to determine the end point for the training process in order to avoid model over fitting. Over-fitting can lead to predictions that are beyond the range of the training data (Richter and Weber, 2013). To avoid model over-fitting, the collected data was randomly divided into a 70:15:15 ratio (Garrido et al., 2014; Kunt et al., 2011; Srisaeng et al., 2015). A cross validation process was carried out during the training phase to avoid over-fitting of the proposed model (Efendigil et al., 2009).

The principal objective of training process is to minimize the global error in the output nodes by adjusting the weights (Nikravesh and Aminzadeh, 2003). ANNs usually commence with randomized weights for all their neurons, and consequently, they need to be trained to solve a specific problem (Ali et al., 2017). The ANNs design process is completed after the weights are determined during the training phase (Sefa et al., 2017).

The training set was used to adapt the synaptic weights of the multilayer network, utilising the back propagation of estimation errors (Kalogirou, 2014). All inputs were inserted into the model and the networks trained. During the supervised learning process, an error function is defined. The synaptic weights values are iteratively updated until the provided output tends to be the desired, and the error function descends along the surface towards a local minimum. In this study the training process stopped when it reached 1,000 epochs or 0.01 error tolerance (Efendigil et al., 2009).

To conclude the training phase, a validation data set was used. The stopping criterion was the mean square error (MSE) of the estimated demand with respect to the samples belonging to the validation set. The validation set was not used in adapting the weight vectors of the neural estimator, and was therefore able to detect over-fitting in the training phase (Alekseev and Seixas, 2009; Srisaeng et al., 2015).

For estimating the generalization capacity of the ANN forecasting model, a testing set was also used (Srisaeng et al., 2015). Thus, after the training process was completed, a testing process was applied to ensure the model accuracy was sufficiently reliable. Once the values of the training set were determined, a data testing set was fed into the model and the output compared to the target value. The model was accepted if the difference was low enough (Garrido et al., 2014). The testing set simulates the forecasting of the samples (Alekseev and Seixas, 2009).

Following the approach of (Ruiz-Aguilar et al., 2014) and (Srisaeng et al., 2015), this study used the Levenberg-Marquardt back propagation algorithm as the training algorithm as its convergence is stable and fast (Ruiz-Aguilar et al., 2014).

Figure 3 presents the study's artificial neural network modelling process. 


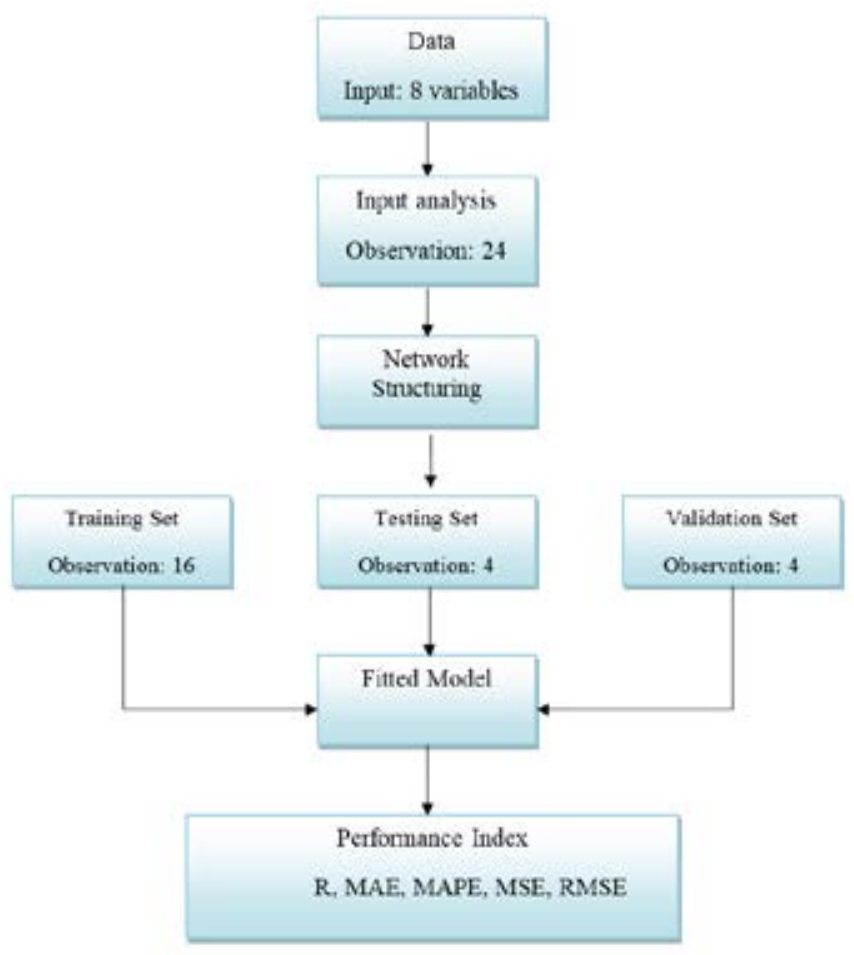

Fig. 3.

The Artificial Neural Network Modelling Process Underpinning the Study Source: Adapted from (Srisaeng et al., 2015, p.288).

\subsection{Artificial Neural Network Transfer Function}

The activation or transfer function is used in an ANN to calculate the output response of a neuron (Sivanandam et al., 2006). The nonlinear relationship that is present in an ANN between the input and output parameters requires a function, which can appropriately connect and/or relate the corresponding parameters. An ANNs neurons transform their net input using an activation or 'scalarto-scalar' function. Activation or transfer functions for an ANNs hidden neurons are required to introduce non-linearity into the network. In the absence of non-linearity, the hidden neurons would not make the ANN more powerful (Khare and Shiva Nagendra, 2007). The selection of the appropriate activation or transfer function substantially influences the ANNs performance (Sharma et al., 2015). The most commonly used transfer or activation functions used in ANNs are the linear or ramp function, threshold function, and the sigmoid function (Senthilkumar, 2010; Terzic et al., 2012). The type of transfer function depends upon the ANNs design (Sharma et al., 2015). A sigmoid function is extensively used for the ANN transfer function (Priddy and Keller, 2005; Sharma et al., 2015). In the current study, the sigmoid function was used in the hidden layer 
and the linear transfer function was used in the output layer. The Artificial Neural Network tool box 8.0 within the MATLAB R2012b (The MathWorks, Inc., USA.) software was used for the ANN modelling and simulation purposes in the study.

\section{Artificial Neural Network Modelling Results}

A Multi-Layer Perceptron (MLP) model was developed and tested in this study. The MLP has three layers each having weight matrix W, bias vector $b$ and output vector pi where $i>1$. The optimum MLP model for predicting Australia's annual export air cargo demand is presented in Figure 4. The number of each layer of the ANN are shown in Figure 4 as a superscript on the variable of interest. This followed the approach of (Kunt et al., 2011) and (Srisaeng et al., 2015) where the authors used superscripts for identifying the source (second index) and also the destination (first index) for the various weights and other elements of the ANN network.

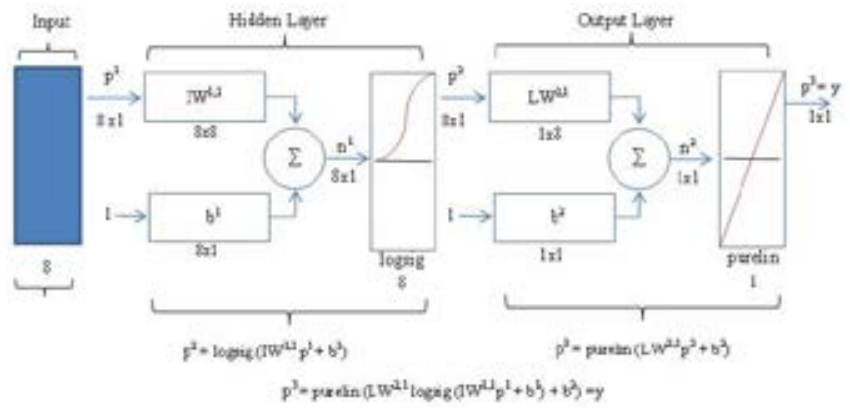

Fig. 4.

The Final Multi-Layer Perceptron Artificial Neural Network Model Structure for Predicting Australia's Annual Export Air Cargo Demand

Source: Based on (Kunt et al., 2011, p.358) and (Srisaeng et al., 2015, p. 293).

In the MLP, the weight matrix that was connected to input vector $p^{1}$, was labelled as input weight matrix $\left(\mathrm{IW}^{1,1}\right)$. The elements of layer 1 (input layer), for instance, its bias, net input and output, have been assigned superscript 1 . This indicates that they were associated with the input layer (layer 1) (Kunt et al., 2011).

As previously noted, the collected data were randomly divided into three sections: training, testing, and validation where 70 per cent of the data were used in the training phase, 15 per cent in the validation phase and 15 per cent in the testing phase. The study's final MLP model had 8 inputs, 8 neurons in the hidden layers and 1 neuron in the output layer. In the output layer one neuron represented Australia's annual export air cargo tonnage.

The results of the Australia's export air cargo demand MLP model are presented in Table 2 in the form of a prediction table. Table 2 shows the prediction level of Australia's export air cargo demand model during training, testing, and validation phases. 
Table 2

Prediction of Australia's Export Air Cargo Demand Model

\begin{tabular}{|c|c|}
\hline $\mathbf{R}$ & Australia's Export Air Cargo Demand Model \\
\hline Training & 0.99893 \\
\hline Validation & 0.99297 \\
\hline Testing & 0.94129 \\
\hline All & 0.97844 \\
\hline
\end{tabular}

Figure 5 shows the regression plots of the Australia's export air cargo demand model output with respect to training, validation and testing data. The value of the correlation coefficient $(R)$ for each phase was also calculated (Srisaeng et al., 2015). The R value was around 0.97844 for the total response in the MLP model. The solid lines in Figure 5 shows the perfect linear fit between the actual values and estimated values of Australia's export air cargo demand model. According to Tiryaki and Aydin (2014), the correlation coefficient (R) between the ANNs actual and estimated values is another important indicator that can be used to verify the validity of the model. These authors have noted that when the $R$ value is close to 1 , the forecasting accuracy increases (Tiryaki and Aydın, 2014).
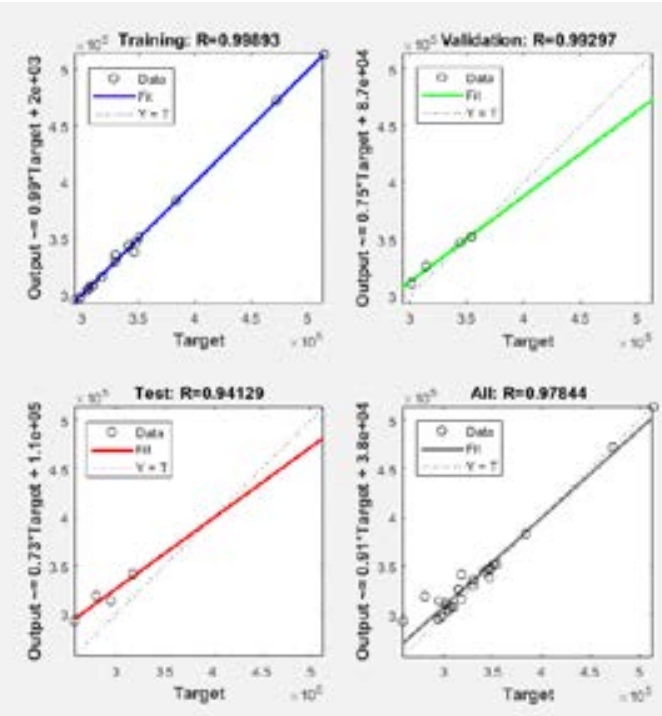

Fig. 5.

Regression Plots for Training, Testing and Validation Phases and the Total Response in Australia's Export Air Cargo MLP Model

Training errors, validation errors and testing errors were plotted to determine validation errors in the training phase for the export air cargo model (Figure 6). The best validation performance in the model occurred at epoch 7 with MSE at $6.1 \times 10^{7}$ (Figure 6). The plot in Figure 6 shows the mean squared error commencing at a large value and decreasing 
to a smaller value, which indicates that network learning is improving. The plot in Figure 6 has three lines, because all input and target vectors were randomly divided into three sets (Garrido et al., 2014; Kunt et al., 2011). As previously noted, 70 per cent of the vectors were used for training the network. 15 per cent of the vectors were used for validating the generalisation abilities of the network (Jazayeri et al., 2016). In this study, the training of the network's vectors continued for as long as it took for the training to reduce the network error on the validation vectors. The training phase concluded when it reached 1,000 epochs or 0.01 error tolerance (Efendigil et al., 2009). This practice ensured that the model was not over-fitted (Kunt et al., 2011; Sathe-Pathak et al., 2016).

To estimate the generalization capacity of the ANN forecasting model, a testing set compromising the remaining 15 per cent of the vectors was used. This set was only presented to the artificial neural estimator following conclusion of the training, and hence, it did not participate in the training phase (Srisaeng et al., 2015).

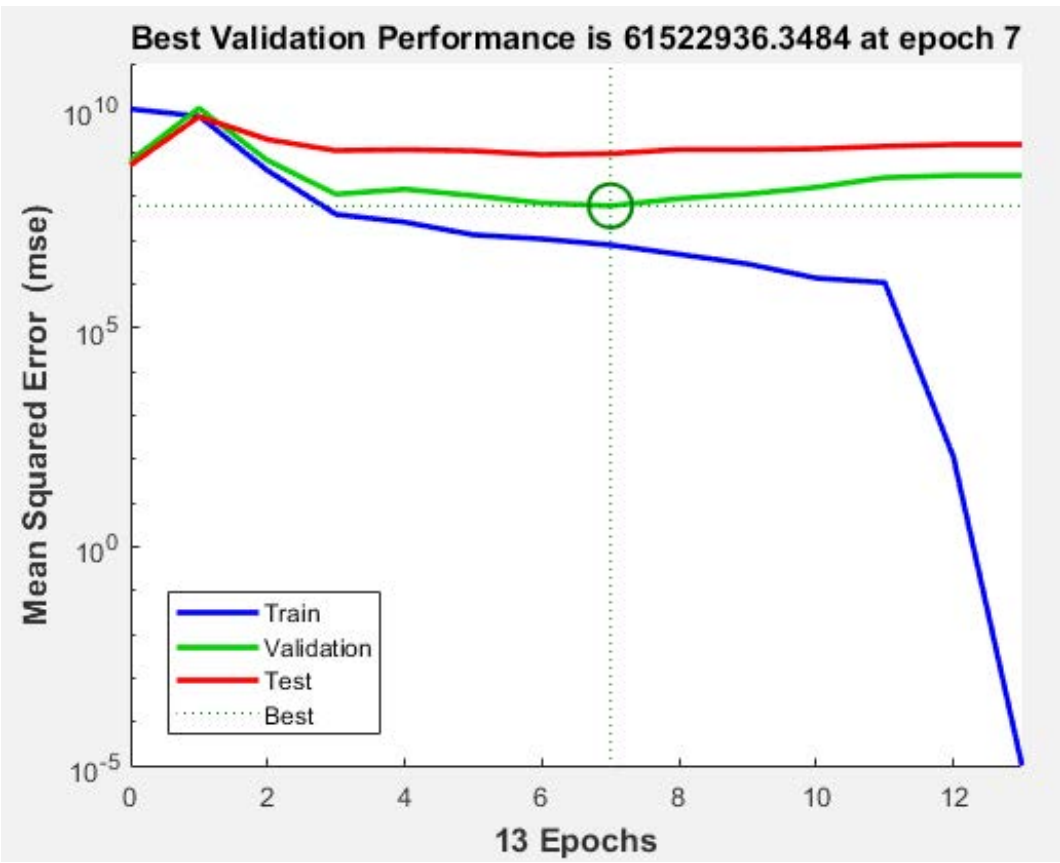

Fig. 6.

The Validation Error in the Australia's Export Air Cargo Model

Australia's actual and estimated Australia's export air cargo demand during 1993 to 2016 are plotted and shown in Figure 7, indicating the accuracy of the estimations. 


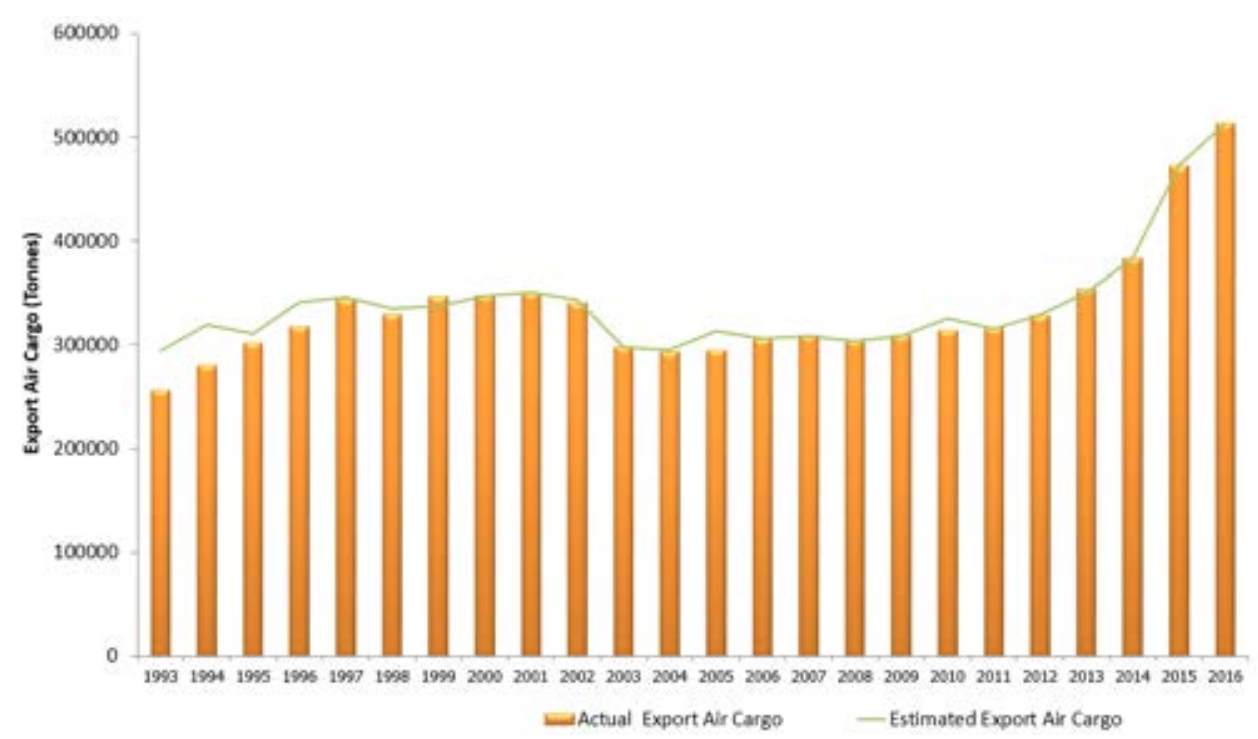

Fig. 7.

A Comparison of Australia's Actual and Estimated Export Air Cargo Demand

This study used an artificial neural network (ANN) to predict Australia's export air cargo demand. Table 3 presents root mean square error (RMSE), mean absolute error (MAE), and mean absolute percentage error (MAPE) of the estimated models. These results suggest that the constructed ANNs are promising for modelling Australia's export air cargo demand.

\section{Table 3}

The Final Results of the Objective Function in Australia's Export Air Cargo Demand ANN Model

\begin{tabular}{|c|c|}
\hline Error & ANN Model \\
\hline MAE & $4.1 \times 10^{3}$ \\
\hline MSE & $1.7 \times 10^{8}$ \\
\hline MAPE & $2.44 \%$ \\
\hline RMSE & $1.3 \times 10^{4}$ \\
\hline
\end{tabular}

This study also used a contribution table (Gately, 1996) to analyse the major contributing factors that influence Australia's outbound airline passenger demand. The contribution of factor $\left(\mathrm{C}_{\mathrm{i}}\right)$ in the input layer is the sum of absolute values of the weight of connection between the input neuron and the hidden neuron.
$C_{i}=\sum_{j=1}^{k}\left|W_{i j}\right|$

The contributing factor scale developed by (Gately, 1996) was used to evaluate the influences of input variables. Based on this scale, any input variable with a contribution value less than 2 is considered a weak contributing factor while any input variable 
with a contribution value greater than 5 is considered a high contributing factor (Chen et al., 2012).

Table 4 shows the contribution value of input variables in Australia's Export Air Cargo Demand model and shows that all the input variables in the model have a contribution value higher than 2 which means that no input variables are considered a weak contributing factor. Also, the four most important input variables for forecasting Australia's Export Air Cargo Demand are: $\mathrm{X}_{1}=$ World Population, $\mathrm{X}_{3}=$ World air cargo yields, $\mathrm{X}_{8}$ Dummy variable for the large fluctuation in Australia's export air cargo growth in 2015, and $\mathrm{X}_{2}$ world real merchandise exports.

\section{Table 4}

The Contributions of the Study's Input Variables

\begin{tabular}{|l|c|}
\hline \multicolumn{1}{|c|}{ Input Variables } & ANN Model \\
\hline $\mathrm{X}_{1}=$ world population & 6.60 \\
\hline $\mathrm{X}_{2}=$ world real merchandise exports & 4.93 \\
\hline $\mathrm{X}_{3}=$ World air cargo yields & 5.20 \\
\hline $\mathrm{X}_{4}=$ Australia's outbound international flight numbers & 4.59 \\
\hline $\mathrm{X}_{5}=$ Australian/United States dollar exchange rate & 3.01 \\
\hline $\mathrm{X}_{6}=$ World jet fuel prices & 4.87 \\
\hline $\mathrm{X}_{7}=$ Dummy variable for 2003 downturn & 3.73 \\
\hline $\mathrm{X}_{8}=$ Dummy variable for Australia's increased air cargo demand in 2015 & 4.97 \\
\hline
\end{tabular}

\section{Conclusion}

Because of Australia's relatively remote geographical location, the international air cargo mode plays a very important role in the country's international trade and economy. In Australia's international air cargo industry, air cargo services are provided by full service network (FSNC) and low-cost carriers (LCCs), dedicated all-cargo airlines and by the integrated carriers, for example, FedEx and United Parcel Service (UPS). Irrespective of the air cargo-carrying airlines business model, forecasting future demand is viewed as being one of the most critical management functions. Furthermore, the long-term forecasting of air cargo demand is also regarded as essential for government and airports for planning and investment decision making purposes. Also, as previously noted, air cargo demand forecasting is critical for analyzing existing cargo flight schedules and identifying air cargo-related firm's future facility requirements.

The objective of this study was to develop an artificial neural network (ANN) model for predicting Australia's annual export air cargo demand. Based on the use of annual data from 1993 to 2016, the ANN model was developed and empirically tested using the input parameters of world real merchandise trade, world population, world jet fuel prices, world air cargo yields (proxy for air cargo costs), outbound flights from Australia, the Australian and United States dollar foreign exchange rate and two dummy variables. The dummy variables were incorporated to control for the impact of the downturn in air cargo demand in 2003 as well as the influence of the increased demand for air cargo services in 2015, which resulted in a significant increase in the annual export air cargo volumes. 
The artificial neural network (ANN) used multi-layer perceptron (MLP) architecture that compromised a multi-layer feed-forward network and the sigmoid and linear functions were used as activation functions with the feed forward-back propagation algorithm. The ANN was applied during training, testing and validation and had 8 inputs, 1 neuron in the hidden layer and 1 neuron in the output layer. The data was randomly divided into three data sets. $70 \%$ of the data was used in the training phase with the remaining data divided into validation (15\%) and testing (15\%). To identify the best-fit model, four goodness-of-fit measures: mean absolute error (MAE), mean square error (MSE), root mean square errors (RMSE), and mean absolute percentage errors (MAPE) were used in the study. The highest R-value obtained from the ANN model is 0.97844 , demonstrating that the ANN provided a high predictive capability.

This study also used a contribution table to analyse the factors that influence Australia's export air cargo demand. The input variables with the highest contributing factor were world population growth (6.60), world air cargo yields (5.20), the Dummy variable that controlled for the large fluctuation in Australia's export air cargo growth in 2015 (4.97), and world real merchandise exports (4.93). These results suggest that the demand for Australia's export air cargo products is dependent upon the growth in the world population, which increases the size of the potential market, transportation costs and the development of world merchandise trade volumes.

\section{References}

Airports Council International. 2004. Chapter 3: Demand forecasting techniques. Available from Internet: <http://www.aci-na.org/sites/default/files/ chapter_3_-_demand_forecasting_techniques.pdf $>$.
Alekseev, K. P. G.; Seixas, J. M. 2009. A multivariate neural forecasting modeling for air transport Preprocessed by decomposition: a Brazilian application, Journal of Air Transport Management 15(5): 212-216.

Ali, M. et al. 2017. Emotion recognition involving physiological and speech signals: a comprehensive review. In book (ed. Kyamakya, K. et al.) Recent Advances in Nonlinear Dynamics and Synchronization: With Selected Applications in Electrical Engineering, Neurocomputing, and Transportation, Springer International Publishing, Switzerland: 287-302.

Australian Bureau of Statistics. 2001. Trade since 1900. Available from internet: <http:// www.abs.gov.au/ausstats/abs@.nsf / Previousproducts/1301.0Feature\%20Article532001>.

BaFail, A.O. 2004. Applying data mining techniques to forecast number of airline passengers in Saudi Arabia (domestic and international travels), Journal of Air Transportation 9(1): 100-115.

Ba-Fail, A.O.; Abed, S.Y.; Jasimuddin, S.M. 2000. The determinants of domestic air travel demand in the Kingdom of Saudi Arabia, Journal of Air Transportation World Wide 5(2): 72-86.

Boeing Commercial Airplanes. 2016. World air cargo forecast: 2016-2017. Available from Internet: <http://www.boeing.com/resources/boeingdotcom/ commercial/about-our-market/cargo-market-detailwacf/download-report/assets/pdfs/wacf.pdf $>$.

Bureau of Infrastructure, Transport and Regional Economics. 2016. International airline activity 2015 statistical report. Available from Internet: < https:// bitre.gov.au/publications/ongoing/files/International_ airline_activity_CY2015.pdf df $>$.

Bureau of Infrastructure, Transport and Regional Economics. 2017. International airline activity 2016 statistical report. Available from internet: <https:// bitre.gov.au/publications/ongoing/files/International airline_activity_CY2016.pdf >. 
Bureau of Transport and Regional Economics. 2004. Air transport statistics: international airlines. Issue number 1/117. Available from Internet: < https://bitre.gov.au/ publications/ongoing/files/International_airline_ activity_CY03_Y.pdf>.

Chen, S.C.; Kuo, S.Y.; Chang, K.W.; Wang, Y.T. 2012. Improving the forecasting accuracy of air passenger and air cargo demand: the application of back-propagation neural networks, Transportation Planning and Technology 35(3): 373-392.

Claveria, O.; Torra, S. 2014. Forecasting tourism demand to Catalonia: neural networks vs. time series models, Economic Modelling 36: 220-228.

Cocchi, M.; Li Vigni, M.; Durante, C. 2017. Chemometrics-Bioinformatics. In book (ed. Georgiou, C.A.; Danezis, G.P.) Food Authentication: Management, Analysis and Regulation. John Wiley \& Sons, Chichester, UK: 481-518.

Cook, G.N.; Billig, B.G. 2017. Airline operations and management: a management textbook. Routledge, United Kingdom. 344 p.

Dell'Olio, L. et al. 2017. Public transportation quality of service: factors, models, and applications. Elsevier. The Netherlands. 242 p.

Doganis, R. 2010. Flying off course: airline economics and marketing. Fourth Edition, Routledge, United Kingdom. $336 \mathrm{p}$.

Efendigil, T.; Önüt, S.; Kahraman, C. 2009. A decision support system for demand forecasting with artificial neural networks and neuro-fuzzy models: a comparative analysis, Expert Systems with Applications 36(3): 66976707.

Garrido, C.; De Oña, R.; De Oña, J. 2014. Neural networks for analyzing service quality in public transportation, Expert Systems with Applications 41(15): 6830-6838.
Gately, E. 1996. Neural networks for financial forecasting. John Wiley \& Sons, Inc, United States. 169 p.

Hamal, K. 2011. International air freight movements through Australian airports to 2030, in Australian Transport Research Forum 2011 Proceedings, 28 - 30 September 2011, Adelaide, Australia. Available from internet: <http://atrf.info/papers/2011/2011_Hamal.pdf >.

Hellermann, R. 2006. Capacity options for revenue management: theory and applications in the air cargo industry. Springer-Verlag, Germany. 199 p.

Hertwig, P.; Rau, P. 2010. Risk management in the air cargo industry: revenue management, capacity options and financial intermediation. Diplomica-Verlag, Germany.76 p.

Howard, R.D.; McLaughlin, G.W.; Knight, W.E. 2012. The handbook of institutional research. Jossey-Bass. United States. 768 p.

International Civil Aviation Organization. 2001. Outlookfor airtransport to the year 2010. Document No. Cir. 281/AT/116. International Civil Aviation Organization, Canada. 49 p.

Jazayeri, K.; Jazayeri, M.; Uysal, S. 2016. Comparative analysis of Levenberg-Marquardt and Bayesian regularization backpropagation algorithms in photovoltaic power estimation using artificial neural network. In book (ed. Perner, P) Advances in Data Mining. Applications and Theoretical Aspects: 16th Industrial Conference, ICDM 2016, New York, July 13-17 Proceedings, Springer International Publishing, Switzerland: 80-95.

Kalogirou, S.A. 2014. Solar energy engineering: processes and systems. Second Edition, Academic Press, United Kingdom. 840 p.

Kar, B.P.; Nayak, S.K.; Nayak, S.C. 2015. Opposition-based GA learning of artificial neural networks for financial timeseries forecasting. In book (ed. Behera, H.S., Mohapatra, D.P.) Computational Intelligence in Data Mining - Volume 2: Proceedings of the International Conference on CIDM, 5-6 December 2015, Springer-India, India: 405-414.

\section{jitte 28}


Kashyap, S.K.; Lolarak, R.; Kumar, L. 2017. Approximation of standing mine support parameters by artificial neural network. In book (ed. Singh, P.K.et.al.) NexGen Technologies for Mining and Fuel Industries. Volume I and II. Allied Publishers India: 575-582

Khan, M.G.M.; Ahmed, S.; Prasad, B. 2015. Forecasting exchange rate of Kina against AUD using artificial neural network and time series models, International Journal of Business Forecasting and Marketing Intelligence 2(1): 37-54.

Khare, M.; Shiva Nagendra, S.M. 2007. Artificial neural networks in vehicular pollution modelling. Springer-Verlag, Germany. 242 p.

Kunt, M.M.; Aghayan, I.; Noii, N. 2011. Prediction for traffic accident severity: comparing the artificial neural network, genetic algorithm, combined genetic algorithm and pattern search methods, Transport 26(4): 353-366.

Kupfer, F. et al. 2011. World air cargo and merchandise trade. In book (ed. Macário, R., Van de Voorde, E.) Critical Issues in Air Transport Economics and Business. Routledge, United Kingdom: 98-111.

Lahmiri, S.; Gagnon, S. 2015. A sequential probabilistic system for bankruptcy data classification. In book (ed. Jakóbczak, D.J.) Analyzing Risk through Probabilistic Modeling in Operations Research. IGI Global, United States: 138-147.

Lefort, C. 2016. Australia air freight crunch hits flights of fancy foods. Available from Internet: <https:// www.reuters.com/article/us-australia-aircargo/ australia-air-freight-crunch-hits-flights-of-fancy-foodsidUSKCN12J0BQ>.

Madden, J.R. 2002. The economic consequences of the Sydney Olympics: the CREA/Arthur Andersen study, Current Issues in Tourism 5(1): 7-21.
Merkus, H.G.; Meesters, G.M.H. 2013. Introduction. In book (ed. Merkus, H.G.; Meesters, G.M.H.) Particulate Products: Tailoring Properties for Optimal Performance. Springer International Publishing, Switzerland: 1-19.

Nachev, A. 2008. Fuzzy ARTMAP neural network for classifying the financial health of a firm. In book (ed. Nguyen, N.T., Borzemski, L., Grzech, A., Ali, M.) New Frontiers in Applied Artificial Intelligence: 21st International Conference on Industrial, Engineering and Other Applications of Applied Intelligent Systems, IEA/AIE 2008, Wroclaw, Poland, June 2008, Proceedings. Springer-Verlag, Germany: 82-91.

Nikravesh, M.; Aminzadeh, F. 2003. Soft computing for intelligent reservoir characterization and modelling. In book (ed. Nikravesh, M., Aminzadeh, F., Zadeh, L.A.) Soft Computing and Intelligent Data Analysis in Oil Exploration, Elsevier Science, United Kingdom: 3-32.

Priddy, K.L.; Keller, P.E. 2005. Artificial neural networks: an introduction. SPIE Press, United States. 180 p.

Productivity Commission. 1998. International air services. Report No. 2, Ausinfo, Australia. 352 p.

Richter, M.M.; Weber, R.O. 2013. Case-based reasoning: a textbook. Springer-Verlag, Germany.

Ruiz-Aguilar,J.J.; Turias, I.J.; Jiménez-Come, M.J. 2014. Hybrid approaches based on SARIMA and artificial neural networks for inspection time series forecasting, Transportation Research Part E: Logistics and Transportation Review 67: 1-13.

Sathe-Pathak, R.; Patil, S.; Panat, A. 2016. Application of three different artificial neural network architectures for voice conversion. In book (ed. Satapathy, S.C., Mandal, J.K., Udgata,S.K., Bhateja, V..) Information Systems Design and Intelligent Applications, Proceedings of Third International Conference India 2016, Volume 2. Springer India, India: 237-246. 
Sefa, I.; Altin, N.; Ozdemir, S. 2017. Maximum power point tracking algorithms for partial shaded PV systems. In book (ed. Bizon, N. et al.) Energy Harvesting and Energy Efficiency: Technology, Methods, and Applications, Springer International Publishing, Switzerland: 261-292.

Senthilkumar, M. 2010. Use of artificial neural networks (ANNs) in colour measurement. In book (ed. Gulrajani, M.L.) Colour Measurement: Principles, Advances and Industrial Applications, Woodhead Publishing Limited, United Kingdom: 125-146.

Sharma, A. et al. 2015. ANN based modeling of performance and emission characteristics of diesel engine fueled with Polanga Biodiesel at different injection pressures, International Energy Journal 15: 57-72.

Shields, M. 1998. The changing cargo business. In book (ed. Butler, G.F., Keller, M.R.) Handbook of Airline Marketing, McGraw-Hill, United States: 183-187.

Sineglazov, V.; Chumachenko, E.; Gorbatyuk, V. 2013. An algorithm for solving the problem of forecasting, Aviation 17(1): 9-13.

Sivanandam, S.N.; Sumathi, S.; Deepa, S.N. 2006. Introduction to Neural Networks Using Matlab 6.0. Tata McGraw Hill Company, India. 656 p.
Srisaeng, P.; Baxter, G.S.; Wild, G. 2015. Forecasting demand for low cost carriers in Australia using an artificial neural network approach, Aviation 19(2): 90103.

Terzic, E. et al. 2012. A neural network approach to fluid quantity measurement in dynamic environments. SpringerVerlag, United Kingdom. 140 p.

Tiryaki, S.; Aydın, A. 2014. An artificial neural network model for predicting compression strength of heat treated woods and comparison with a multiple linear regression model, Construction and Building Materials 62:102-108.

Totamane, R.; Dasgupta, A.; Rao, S. 2012. Air cargo demand modeling and prediction, IEEE Systems Journal 8(1): 52-62.

Watts, M.J.; Worner, S.P. 2008. Using artificial neural networks to determine the relative contribution of abiotic factors influencing the establishment of insect pest species, Ecological Informatics 3(1): 64-74. 